\title{
Do Perceptions of Gifted Intelligence and Normal Intelligence Participants Differ About Social Science and Social Scientists?
}

\author{
Sezgin Selvi ${ }^{1} \&$ Selçuk Beşir Demir ${ }^{2, *}$ \\ ${ }^{1}$ Education Faculty, Cumhuriyet University, 58100 Sivas, Turkey \\ *Correspondence: Education Faculty, Cumhuriyet University, 58100 Sivas, Turkey. E-mail: sbesdem@hotmail.com
}

Received: November 3, 2017

Accepted: November 11, 2017 Online Published: November 26, 2017

doi:10.5430/jct.v6n2p90

URL: https://doi.org/10.5430/jct.v6n2p90

\begin{abstract}
This qualitative study was conducted to compare the perceptions of students with gifted intelligence and students with those of normal intelligence about social science and social scientists. The data obtained from 23 gifted intelligent and 23 normal participants within the same age group was analysed using content analysis and results were represented with a straight and systematic language. A significant part of normal participants confused social science teacher with social scientist. Both groups find a social scientist happy. Social scientist was represented as young and dynamic, was thought without hindrance as well. As a common finding, gender is significant for both groups and males were distinguished. They do not sufficiently recognise social scientists. However, normal intelligence participants confuse social sciences with the natural sciences and they give names of both natural scientists and inventors instead of social scientists.
\end{abstract}

Keywords: gifted intelligent participants; normal participants; social science; perception of social science

\section{Introduction}

The purpose of science is to understand the world in which we live and work (Babbie, 1990). Human intention to understand, explain, and control the world is the domain of the natural sciences, whereas the intention to understand and explain human and society is the domain of the social sciences. The concept of nature significantly changed with the rise of modern science (Bristow, 2010). When viewed this way, while improvements in natural science are effective in the emergence of social science, the necessity of examining social events reveals an important sphere of influence in the improvement of social sciences. The term social science expresses the scientific examination of human behaviour. If the purpose of science is creating explanatory theory about its own data, the target of social science is creating explanatory theory about human and human behaviours (Punch, 2014).

Gadamer (1994) argued that the concept of modern science was shaped through improvements in natural sciences. Soysal (2012) suggested that the word science's evolution to correspond with natural science was rooted in using scientific knowledge as empirical knowledge. Neuman (2014) emphasized that natural science is the first thing that comes to mind when the subject of science is raised and fewer people conflate it with anthropology, psychology, politics, and sociology.

Yıldırım and Şimşek (2005) suggest that in the twentieth century, when social science researchers found themselves working in the positivist/rationalist paradigm of the physical sciences, they attempted to explain both human and societal behaviour in terms of the causality principle, which is proper core of positivist paradigm owing to be bred up to the same paradigm. However, based on the belief that there is no unique reality in social sciences, researchers started to articulate its essential concepts and research methods. It is in this sense, then, that the reconstruction of the social sciences and debates took place

The Gulbenkian Commission's report (1994) published during Professor Wallerstein's tenure as president, is one of the important studies in the literature on the reconstruction of the social sciences. In this report, structural and hierarchical revitalization of universities' disciplines discussed as promoting the improvement of social science's re-institutionalization. With the acceleration of efforts to explain the social change created by the French revolution, the distinctive feature of the nineteenth century intellectual history is emphasized as professionalization and branching out of the knowledge. 
Esgin and Aslan (2011) held that social science debates remain incapable and both theoretical and methodological orientations are problematic and have a long history. With regards to these debates, social sciences cannot fulfil expectations sufficiently and fail to come up against rapid changes. As the most important cause of failure there are often indications of uncertainties in terms of its science description.

Neuman (2004) noted that when science was mentioned, the first images that come to many people are test tubes, computers, space rockets, and people wearing white lab coats. In this context, there are too many studies conducted about sciences and scientists in Social science literature especially from the United States. Science and scientist perceptions of students were measured in many of these studies. Research was generally conducted about the natural sciences (Beardslee \& O’Dowd, 1961; Camcı \& Erdoğan, 2013; Chambers, 1983; Demirbaş, 2009; Kara \& Akarsu, 2013; Song \& Kim, 1999; Turgut, Öztürk, \& Eş, 2017) and measuring secondary school students' perceptions of science and scientists. However, social scientists are uncertain what science means to them and to their work (Demirbaş \&Coşkun, 2014).

The only way to spread the sciences' social and cultural influences are through an understanding of the nature of science and furthering the perception of science. Turgut, Öztürk, and Eş (2017) emphasized that a healthy scientific perception is important to the whole society; but the perceptions of science and scientist by gifted intelligence students, who are more likely to choose professions in which scientific knowledge is heavily used or have more potential of becoming a scientist in the future, will be more important in terms of their preferences.

Related literature to this study has been reviewed; however, any study that investigates the perceptions of both social science and social scientists among gifted intelligence and normal intelligence individuals has yet to be done. For the most part, studies in the literature focus only on social science. Hence, this study will be the first to examine perceptions of social science and social scientists among individuals of gifted and normal intelligence. In this context, the aim of this study is to reveal the perceptions of both gifted intelligence and normal intelligence individuals about social science and social scientists. Results will be derived from the study are important to forming the basis for developing strategies to construct positive perceptions. Of both social science and social scientists.

\section{Method}

\subsection{Research Design}

For revealing an existent situation, the research was patterned according to the case study method, which is a qualitative research approach. The main objective if the study is to present results related to the participants' perceptions of social science and social scientists.

\subsection{Sample Group}

The study participants consisted of two groups of secondary school students: one group of gifted intelligence students who study in the Public Science and Art Centre; and a second group of students of normal intelligence who study in public schools located in the Central Anatolia Region of Turkey. Through purposeful sampling, the study sample consists of 23 gifted intelligence and 23 normal intelligence students within the same age group. Demographic features of study group were presented in Table-1.

Table 1. Participants' Distribution According to Class Level and Gender

\begin{tabular}{lllll}
\hline & \multicolumn{2}{l}{ Gifted Intelligent Participants } & \multicolumn{2}{l}{ Normal Participants } \\
\hline & Gender & M & Gender & F \\
Class Level & F & 7 & 6 & M \\
$5^{\text {th }}$ class & 8 & 1 & 3 & 3 \\
$6^{\text {th }}$ class & 3 & 2 & 2 & 3 \\
$7^{\text {th }}$ class & 2 & & $\mathbf{2 3}$ & \\
Total & $\mathbf{2 3}$ & & \\
\hline
\end{tabular}

\subsection{Data Collection}

After your literature review, you note that no one has tried to measure perceptions of the social science and social scientist. Chambers' (1983) Draw-a-Scientist Test (DAST) was designed to measure perceptions of social science and social scientists. In this measure, participants were asked to image a social scientist and to draw their image on paper. After the digitalization of drawings, mental images, physical images, and so forth of social scientists, the 
results were tabularized in NVivo 11 software. Then, based on interesting samples' codes and expert opinions the 'Image Source's Interview Form of Scientist' was created. So, DAST tried to determine the participants' perceptions of social scientist. Semi-structured and open-ended questions were asked to determine their future preferences whether to become a social scientist. Data collection tools and informed consents were reviewed by the Ministry of Education's unit and the research ethics commission and allowed by the ethics commission.

\subsection{Data Analysis}

Content analysis is a qualitative method for examining data derived from participants' drawings and interview forms. From the interviews, we developed a frame for data analysis shaped from the structure of the interview. Data were represented systematically and clearly. The study's intention is to reflect the views of the interviewed individuals in an interesting way and citations were directly ad dressed. The generated frame shows that some of data are inexpedient and therefore left out of study. Codes and themes were determined, and data inductively gathered within the scope of particular concepts and themes so that frequencies and percentages of codes and themes were derived from the data (Yıldırım \& Şimşek, 2005). Gifted intelligence students participated in the research were coded as ÜK-1, ÜK-2, ÜK-3....̈K-23; normal intelligence students were coded as NK-1, NK-2, NK-3 ....NK-23.

\section{Findings}

\subsection{Social Scientists' Mental Images According to Participants}

We analysed the participants' social scientist mental images, which were coded as: multiple perspectives, convenience of self-expression, powerful communication, visual intelligence, investigation, oratory, and problem solving.

Table 2. Mental Images of Social Scientists

\begin{tabular}{lcccc}
\hline & $\begin{array}{c}\text { Social Scientists' Mental } \\
\text { Images According to } \\
\text { Gifted Intelligent } \\
\text { Participants } \\
\text { (f) }\end{array}$ & $\%$ & $\begin{array}{c}\text { Social Scientists' Mental } \\
\text { Images According to } \\
\text { Normal Participants } \\
\text { (f) }\end{array}$ & $\%$ \\
\hline Multiple perspective & 8 & 34.7 & 8 & 34.7 \\
Convenience of self-expression & 18 & 78.2 & 15 & 65.2 \\
Powerful communication & 5 & 21.7 & 3 & 13 \\
Visual intelligence & 16 & 69.5 & 1 & 4.3 \\
Research & 12 & 52.1 & 4 & 17.3 \\
Oratory & 4 & 17.3 & 4 & 17.3 \\
Problem solving & 4 & 17.3 & 3 & 13 \\
\hline
\end{tabular}

Student participants perceived a social scientist as a person who investigates, has multiple perspectives, eloquent, and who can solve problems. These characteristics allow social scientists convenience of self-expression and powerful communication. The participants revealed that they have an extensive verbal-linguistic intelligence. Self-expression, extroversion, and communicative competence for social scientist are common images from both participant groups. Multiple perspective images for students of both groups are equal.

While the 'research' image was repeated 12 times in the gifted intelligence group, this number decreased by two-thirds in normal intelligence group. When the participants who gave this answer were asked why they associated the social scientist with the research, ÜK-4 stated, 'social scientist does research in order to show the facts about life', while ÜK-7 said 'social scientist does research because the essence of science is researching' and this answer referred to the core of the science. ÜK-18 said 'Research is needed to become a scientist'. Only four of the normal intelligence students associated a social scientist with the research image.

The normal intelligence student's answers given to open-ended questions in evaluating the relationship between social scientist and research included NK-14 who said 'social scientist does researches in the field of social science areas'. NK-9 also added that 'social scientist researches society issues and try to reach evidences'. Looking at these answers, while it is possible to suggest that normal intelligence participants have a healthy perception of social scientists, NK-5's answer of 'social scientist do researches about experimental issues', it is more likely that they confused natural scientist with social scientist. Gifted intelligence participants never referred to natural sciences in 
their answers. Meanwhile, NK-3 emphasised social scientist's instructive aspect dwelling on the basis that social scientist does research to convey his/her teachings. As the answer implies, there is a strong link between social scientists in the minds of gifted intelligence participants and doing research while this link is weaker among normal intelligence participants.

\subsection{Social Scientists' Physical Images According to Participants}

When the physical images of the social scientist are described by the participants, they include characteristics, such as young, elegant, tall, without disability, thin. Participants generally perceived as young and dynamic.

Table 3. Physical Images of Social Scientists

\begin{tabular}{lcccc}
\hline & $\begin{array}{c}\text { Social Scientists' } \\
\text { Physical Images } \\
\text { According to Gifted } \\
\text { Intelligence Participants } \\
\text { (f) }\end{array}$ & $\begin{array}{c}\text { Social Scientists' Physical } \\
\text { Images According to Normal } \\
\text { Intelligence Participants } \\
\text { (f) }\end{array}$ & $\%$ \\
\hline Wearing glasses & 2 & 8.6 & 0 & - \\
Without glasses & 17 & 73.9 & 18 & 78.2 \\
Young & 12 & 52.1 & 12 & 52.1 \\
Middle-aged or old & 4 & 17.3 & 6 & 26 \\
Elegant & 10 & 43.4 & 8 & 34.7 \\
Shabby & 8 & 34.7 & 8 & 34.7 \\
Cheerful & 14 & 60.8 & 13 & 56.5 \\
Tall & 14 & 60.8 & 10 & 43.4 \\
Short & 5 & 21.7 & 2 & 8.6 \\
Without disability & 19 & 82.6 & 13 & 56.5 \\
Undetermined or disabled & 4 & 17.3 & 4 & 17.3 \\
Thin & 13 & 56.5 & 12 & 52.1 \\
Fat & 3 & 13 & 6 & 26 \\
Bald & 5 & 21.7 & 4 & 17.3 \\
\hline
\end{tabular}

Among gifted intelligence and normal intelligence participants, 52.1\%saw social scientists as young. When gifted intelligence participants were asked why they drew social scientists as young ÜK-6 emphasised that 'The young has a better potential for doing research', and ÜK-2 stated that 'It is important for social scientist to comply with innovations because science has improved further'. ÜK-19 referred to social scientist's youth expressing that 'Scientists usually starts researching at a young age'. For normal intelligence students it was $70 \%$, which shows a significant finding that there is a common point in the images of both groups. Comparing youth with the elderly, NK-8 pointed out the reason why the social scientist is young and concluded that youth understand children better. NK-13, who imagined himself as a social scientist in the future, said 'I didn't want to draw as old because I associated social scientist with myself". NK-20 has an idea that "Young people are more innovative'. NK-10 and NK-5 made a similar comparison: 'Young people have more detailed knowledge, offer more dynamic and good ideas as well'.

While social scientists do not have any disabilities according to 19 of the gifted intelligence participants, this number is 13 for normal intelligence participants. While none of the participants particularly draw any disability, there are four participants in both groups who are uncertain or draw disability. When asking gifted intelligent participant why they drew no disability; ÜK-11 answered as 'there is no particular reason and they can have even disability', by the way, ÜK*5, ÜK-1, ÜK-14 and ÜK-7 stated that 'It is important for social scientists to move comfortable and having a disability could constrain them'. Thinking like ÜK-11, other gifted intelligence participants said that 'The first thing coming to the mind is an image without disability'.

Looking at the answers, the fact that people with disabilities are present in other parts of society as well as scientists cannot be considered, can be handled as an important sociological finding. Possibly, the perceptions in this subject overlap with the gifted intelligence participants, since the normal intelligence participants also gave similar answers to the same question. For both groups of participants, clearly the perception that the social scientist is usually without glasses disambiguated the idea that dealing with social science is not so hard. 


\subsection{Social Scientist's Gender According to Participants}

Table 4. Social Scientist’S Gender

\begin{tabular}{lcccc}
\hline & $\begin{array}{c}\text { Social Scientist's Gender } \\
\text { According to Gifted Intelligent } \\
\text { Participants }\end{array}$ & \multicolumn{3}{c}{$\begin{array}{c}\text { Social Scientist's Gender } \\
\text { According to Normal } \\
\text { Participants }\end{array}$} \\
\hline (f) & $\%$ & (f) & $\%$ \\
\hline Female & 17 & 73.9 & 7 & 30.4 \\
Both & 2 & 8.6 & 1 & 4.3 \\
\hline
\end{tabular}

For $52.1 \%$ of the gifted intelligence participants a social scientist is male whereas only $30.4 \%$ of normal intelligence participants imaged them as male. One student imaged the social scientist as both male and female. When gifted intelligence participants were asked why a social scientist should be a man, ÜK-4 explained that 'Men are more venturesome', while ÜK-11 said 'Men are more energetic'. ÜK-15 thought that 'Men are generally more interest in social science,' while ÜK-17 made a comparison that 'Women select social science less than men'. Especially, it is a remarkable finding that girls do not make an identity with them and perceive scientist as men. NK-18 stated as 'Men become a scientist mostly' and NK-6 expressed that 'Men go in for science more than women'. NK-4, by the way, confused social science teacher with social scientist and said, 'I drew social scientist as a man because social scientist is male'. The results in Table 4 show that participants of both groups disconnect the social scientist's gender from science yet they did not see gender as insignificant; quite the contrary, they showed that gender is distinctly important and assumed the gender to be male.

\subsection{Social Scientist's Study Areas According to Participants}

Participants perceived social scientist's study area mostly as social life. The finding supports the fact that social sciences are a common group of people and societal sciences and that most participants have developed their perceptions in this respect.

Table 5. Study Area of the Social Scientist

\begin{tabular}{|c|c|c|c|c|}
\hline & $\begin{array}{l}\text { Social Scientists' Study } \\
\text { Area According to Gifted } \\
\text { Intelligent Participants } \\
\text { (f) }\end{array}$ & $\%$ & $\begin{array}{c}\text { Social Scientists' Study Area } \\
\text { According to Normal } \\
\text { Participants } \\
\text { (f) }\end{array}$ & $\%$ \\
\hline Social life & 10 & 43.7 & 11 & 47.8 \\
\hline Excavation site & 7 & 30.4 & 0 & - \\
\hline School or classroom & 0 & - & 8 & 34.7 \\
\hline Laboratory & 0 & - & 1 & 4.3 \\
\hline Nature & 2 & 8.6 & 0 & - \\
\hline Individual and Society & 6 & 26 & 9 & 39.1 \\
\hline International Society & 2 & 8.6 & 3 & 13 \\
\hline Library & 1 & 4.3 & 0 & - \\
\hline Historical place & 1 & 4.3 & 0 & - \\
\hline Museum & 1 & 4.3 & 0 & - \\
\hline A large and ordinary area- table & 1 & 4.3 & 2 & 8.6 \\
\hline Office & 4 & 17.3 & 0 & - \\
\hline
\end{tabular}

While 18 of the gifted intelligence participants symbolized individual and society, social life, and international society, this number is 22 in normal intelligence participants' group. Gifted intelligence participants did not draw any school or classroom symbols while eight normal intelligence participants saw the study area of social scientist as school or classroom. Accordingly, an important source of social scientist images for the normal intelligence participants is the social science teacher.

\subsection{Social Scientist's Happiness According to Participants}

The results from participants' drawings symbolized a social scientist as usually happy. One student from gifted intelligence and three students from normal intelligence groups drew uncertain or unhappy images. 
Table 6. Social Scientist's Happiness

\begin{tabular}{llcllc}
\hline & $\begin{array}{l}\text { Social Scientists' Happiness } \\
\text { According to Gifted Intelligent } \\
\text { Participants } \\
\text { (f) }\end{array}$ & $\%$ & $\begin{array}{l}\text { Social } \\
\text { Happiness According to } \\
\text { Normal Participants } \\
\text { (f) }\end{array}$ & $\%$ \\
\hline Happy & 17 & 73.9 & 16 & 69.5 \\
Uncertain or unhappy & 1 & 4.3 & 3 & 13 \\
\hline
\end{tabular}

ÜK-11, who is one of the gifted intelligence participants and drew social scientists as happy, noted that 'Happiness is rooted in cohesion ability with national or international society'. Meanwhile, ÜK-7 stated that 'Doing the profession nicely is also effective in happiness'. Participants perceived social scientists as successful people because doing business well is important to success. Seventeen of the gifted intelligence participants described social scientists as happy and 16 normal intelligence participants. When normal intelligence participants were asked why they drew social scientist as happy, NK-5 said 'Because society avails of them'. Accordingly, participants described the social scientist as having a peaceful image with either native or international society as people who enjoy dealing with science. NK-15 confused social scientists with inventors as shown in the answer of 'Because of finding something not existed'. NK-3 and NK-8 said that 'While the social scientist was happy to get the correct answer to the question he/she asked, he/she also preferred to be a cheerful person by lecturing at the same time'. The answer pointed to the social science teacher and repeated that it is an important image source.

\subsection{Research Subjects Used by the Social Scientist According to Participants}

For the participants, the object of social scientist's research is human beings. Thus, the reason for the execution of social science is the human being, as the human being performs the science.

Table 7. Objects Used by Social Scientist

\begin{tabular}{|c|c|c|c|c|}
\hline & $\begin{array}{l}\text { Objects Used by Social } \\
\text { Scientists According to } \\
\text { Gifted Intelligence } \\
\text { Participants } \\
\text { (f) }\end{array}$ & $\%$ & $\begin{array}{l}\text { Objects Used by Social } \\
\text { Scientists According to } \\
\text { Normal Intelligence } \\
\text { Participants } \\
\text { (f) }\end{array}$ & $\%$ \\
\hline Human & 6 & 26 & 14 & 60.8 \\
\hline Survey & 2 & 8.6 & 0 & - \\
\hline Digital translator & 1 & 4.3 & 0 & - \\
\hline Book & 4 & 4.3 & 4 & 17.3 \\
\hline Excavation Equipment & 4 & 4.3 & 0 & - \\
\hline Lens & 1 & 4.3 & 0 & - \\
\hline Map & 2 & 8.6 & 1 & 4.3 \\
\hline Sphere & 1 & 4.3 & 0 & - \\
\hline Board & 1 & 4.3 & 6 & 26 \\
\hline Microphone & 0 & - & 3 & 13 \\
\hline Computer & 1 & 4.3 & 1 & 4.3 \\
\hline Test tubes & 0 & - & 1 & 4.3 \\
\hline Speech bubbles & 3 & 13 & 1 & 4.3 \\
\hline Questions and interrogation marks & 1 & 4.3 & 1 & 4.3 \\
\hline File & 0 & - & 1 & 4.3 \\
\hline Money & 1 & 4.3 & 0 & - \\
\hline
\end{tabular}

Unexpectedly, according to six gifted intelligent participants, human beings are one of the research items for social scientists while this number is 14 for normal intelligence participants. Gifted intelligence participants chose the book as the most used object after human beings while the second most used object is the chalkboard for normal intelligence participants. Another point worth noting is that microphones are among the objects used by the social scientist for normal intelligence participants. This situation indicates that social scientist directly keeps in touch with the society via conferences. In both groups, social scientists' use of digital or technological tools has been realized at a low level. Accordingly, social scientists stay in the classical understanding, thus digital components, such as computer, and 
tablets becomes unnecessarily. Based on this data, for both groups the main characteristic of the social scientist is an interest in human beings or society.

\subsection{Social Scientist's Activities According to Participants}

When social scientists' activities are compared, the perceptions of gifted intelligence participants and normal intelligence participant differ.

Table 8. Social Scientist's Activities

\begin{tabular}{lcccc}
\hline & $\begin{array}{c}\text { Social Scientist's } \\
\text { Activities According to } \\
\text { Gifted Intelligence } \\
\text { Participants } \\
\text { (f) }\end{array}$ & $\%$ & $\begin{array}{c}\text { Social Scientist's } \\
\text { Activities According to } \\
\text { Normal Intelligence } \\
\text { Participants } \\
\text { (f) }\end{array}$ & $\%$ \\
\hline Excavation & 8 & 34.7 & 0 & - \\
Conference & 0 & - & 3 & 13 \\
Survey & 1 & 4.3 & 0 & - \\
Terrain trip & 4 & 17.3 & 0 & - \\
Research-data collection & 5 & 21.7 & 2 & 30.4 \\
Lecturing & 0 & - & 7 & 21.7 \\
Question-answer & 1 & 4.3 & 5 & 4.3 \\
Colloquial language-rhetoric & 1 & 4.3 & 1 & 4.3 \\
Experiment & 0 & - & 1 & \multicolumn{3}{c}{} \\
\hline
\end{tabular}

For gifted intelligence participants, the most common activity of social scientist is excavation. This symbol overlaps with the finding that archaeology is one of the prominent disciplines for a social scientist. The answers given to open-ended questions show that the reason for the symbolization of excavation equipment by gifted intelligence participants is their stronger perception about archaeology. The archaeologist's adventurous attitude of archaeologist may have attracted more attention to this age group of children. Accordingly, it can be said that the desire of gifted intelligent male participants to become archaeologists is higher than normal participants.

In normal participants, the most imaginative activity was lecturing. Question-answer which is one of the symbolized activities is also associated with this finding. According to this; it is once again emphasized that the sources of social scientist images of normal participants are social science teachers. Researching and collecting data through reference books was observed in drawings of 5 gifted intelligent participants, while this number is two for normal participants. The finding reveals both normal and gifted intelligence participants own perceptions of researching and that research factors for normal intelligence participants are lower.

\subsection{Optimal Discipline Field for Social Scientist According to Participants}

For $39.1 \%$ of gifted intelligence participants, geography is recognisable discipline for social scientist. Based on results derived from drawings, geography was followed by archaeology with $34.7 \%$ and after philosophy with $21.7 \%$. When the gifted intelligence participants were asked why they chose archaeology, ÜK-17 said, 'Social sciences are founded on research, research elements are also dominant in archaeology'. In contrast to gifted intelligence participants, $34.7 \%$ of normal intelligence participants mostly imaged social studies instead of social sciences. Thus, this finding draws attention to the educator side of the social scientist and normal intelligence participants confused social scientist with social science teacher. Finally, as seen in Table 9, gifted intelligence participants can perceive social sciences specifically as philology, theology, psychology, and economics, whereas normal intelligence participants perceive the more general disciplines, such as geography and sociology. 
Table 9. Optimal Discipline Field for Social Scientists

\begin{tabular}{|c|c|c|c|c|}
\hline & $\begin{array}{l}\text { Favourite Discipline Field for Social } \\
\text { Scientists According to Gifted Intelligent } \\
\text { Participants } \\
\text { (f) }\end{array}$ & $\%$ & $\begin{array}{l}\text { Favourite Discipline Field } \\
\text { for Social Scientists } \\
\text { According to Normal } \\
\text { Participants } \\
\text { (f) }\end{array}$ & $\%$ \\
\hline Geography & 9 & 39.1 & 7 & 30.4 \\
\hline Archaeology & 8 & 34.7 & 0 & - \\
\hline Philosophy & 5 & 21.7 & 0 & - \\
\hline Psychology & 1 & 4.3 & 0 & - \\
\hline Education & 0 & - & 1 & 4.3 \\
\hline Law & 1 & 4.3 & 1 & 4.3 \\
\hline Sociology & 0 & - & 4 & 17.3 \\
\hline History & 2 & 8.6 & 0 & - \\
\hline Philology & 2 & 8.6 & 0 & - \\
\hline Communication & 2 & 8.6 & 11 & 47.8 \\
\hline Theology & 1 & 4.3 & 0 & - \\
\hline Social studies & 0 & - & 8 & 34.7 \\
\hline Economics & 2 & 8.6 & 0 & - \\
\hline Astronomy & 1 & 4.3 & 0 & - \\
\hline Geology & 1 & 4.3 & 0 & - \\
\hline Uncertain & 1 & 4.3 & 4 & 17.3 \\
\hline
\end{tabular}

\subsection{Favourite Social Scientist According to Participants}

Ask them to name a favourite? It makes a difference in how the results are discussed. While $86.9 \%$ of gifted intelligence participants did not name a favourite social scientist, Ibni Sina was the name given most frequently, whereas $78.2 \%$ of normal intelligence participants did not name a favourite social scientist.

Table 10. Favourite Social Scientist

\begin{tabular}{lcccc}
\hline & $\begin{array}{c}\text { Favourite Social Scientist } \\
\text { According to Gifted Intelligent } \\
\text { Participants } \\
\text { (f) }\end{array}$ & $\%$ & $\begin{array}{c}\text { Favourite Social Scientist According } \\
\text { to Normal Participants } \\
\text { (f) }\end{array}$ & $\%$ \\
\hline Ibn Sina & 2 & & 1 & 4.3 \\
Newton & 0 & -6.6 & 1 & 4.3 \\
Aristotle & 1 & - & 1 & 4.3 \\
Graham Bell & 0 & - & 1 & 4.3 \\
Edison & 0 & - & 1 & 4.3 \\
Galileo & 0 & - & 1 & 4.3 \\
\hline
\end{tabular}

Even though the gifted intelligence participants can distinguish between social sciences and natural sciences, they repeatedly suggested that Ibn Sina was a natural scientist (medicine) when they were asked to name a social scientist. If we accept Ibn Sina as a social scientist, the fact that $86.9 \%$ of gifted intelligence participants were unable to name a social scientist indicates that their perception of social science is high while their perception of social scientists is low. Even though the question of social scientist were directed to normal intelligence participants, NK-23 answered 'Newton', NK-18 answered 'Graham Bell', NK-9 answered 'Edison', and NK-16 answered 'Galileo'. In other words, they named natural scientists and inventors. The finding demonstrates that normal intelligence participants also have lower social scientist perceptions as with social science, and that they do not have sufficient recognition of social scientists.

\subsection{Research Subjects of Social Scientists According to Participants}

Table 11 shows that the most common research subjects for a social scientist is archaeological finds according to $47.8 \%$ of the gifted intelligence participants. This result is parallels to the choice of archaeology as an optimal discipline for social scientists. Despite this, the strong archaeological perceptions of the gifted intelligence participants can be 
explained by their curiosity and knowledge shifting in this direction.

Table 11. Research Subjects of Social Scientists

\begin{tabular}{|c|c|c|c|c|}
\hline & $\begin{array}{l}\text { Research Subjects of } \\
\text { Social Scientists } \\
\text { According to Gifted } \\
\text { Intelligent Participants } \\
\text { (f) }\end{array}$ & $\%$ & $\begin{array}{l}\text { Research Subjects of Soc } \\
\text { Scientists According to } \\
\text { Normal Participants } \\
\text { (f) }\end{array}$ & $\%$ \\
\hline Wars & 0 & - & 1 & 4.3 \\
\hline Symbolic monuments & 0 & - & 1 & 4.3 \\
\hline Technology and inventions & 0 & - & 5 & 21.7 \\
\hline Transportation & 0 & - & 1 & 4.3 \\
\hline Civil rights and values & 0 & - & 1 & 4.3 \\
\hline Sociological concepts & 0 & - & 4 & 17.3 \\
\hline Directions & 2 & 8.6 & 0 & - \\
\hline Steam Power & 1 & 4.3 & 0 & - \\
\hline Career choice & 0 & - & 1 & 4.3 \\
\hline Communication & 1 & 4.3 & 4 & 17.3 \\
\hline Historical figure & 2 & 8.6 & 0 & - \\
\hline Socialization & 2 & 8.6 & 0 & - \\
\hline Regimes & 1 & 4.3 & 0 & - \\
\hline Earthquake & 1 & 4.3 & 0 & - \\
\hline World peach & 0 & - & 4 & 17.3 \\
\hline World & 1 & 4.3 & 6 & 26 \\
\hline Modern astronomy & 1 & 4.3 & 1 & 4.3 \\
\hline Topographic features & 1 & 4.3 & 0 & - \\
\hline Archaeological finds & 11 & 47.8 & 0 & - \\
\hline Geography of Turkey & 1 & 4.3 & 0 & - \\
\hline Country flags & 1 & 4.3 & 0 & - \\
\hline Scientific journey & 2 & 8.6 & 0 & - \\
\hline Survey & 1 & 4.3 & 0 & - \\
\hline Uncertain & 3 & 13 & 6 & 26 \\
\hline
\end{tabular}

The research subject chosen most for normal intelligence participants was 'World'. Both geographically and culturally, the social scientist's perception of research interests is not limited to the society and geography (country) in which he/she lives. Accordingly, for $26 \%$ of normal intelligence participants, the whole world in its entirety is the field of study for a social scientist. The removal of research limits points to a comment from the group of normal intelligence participants that the desire of science for both world and human beings is more prevalent than in the group of gifted intelligence participants. For $13 \%$ of the gifted intelligence participants, the research subject of the social scientist was uncertain while this rate doubled to $26 \%$ for normal intelligence participants. The data shows that the existence of uncertainty for research subject of social scientists can be considered as evidence of an ambiguity in the meaning of science.

\subsection{Relation between Social Science and Natural Science According to Participants}

While $87.4 \%$ of gifted intelligence participants can roughly distinguish social science from natural science, they have specifically visualized astronomy and geology as social sciences.

The data from open-ended questions shows that when asking why do not establish a relationship with natural science, ÜK-3 said 'Social science will be corrupted if we add natural science items', while ÜK-22 noted 'physical science are from natural sciences but social sciences are from human sciences'. And, interestingly, ÜK-17 said 'Social sciences are about human and society while natural sciences are about living being and organisms'. As clearly understood from answers, $8.6 \%$ of gifted intelligent participants confuse social science with natural science and $34.7 \%$ for normal intelligence participants. 
Table 12. Relationship between Social Science and Natural Science

\begin{tabular}{lcccc}
\hline & $\begin{array}{c}\text { Attribution of Gifted Intelligence } \\
\text { Participants to Social Science with } \\
\text { Natural Science } \\
\text { (f) }\end{array}$ & $\begin{array}{c}\text { Attribution of Normal Intelligence } \\
\text { Participants to Social Science with } \\
\text { Natural Science } \\
\text { (f) }\end{array}$ & $\begin{array}{c}\text { \% } \\
\%\end{array}$ \\
\hline Physics & 0 & - & 4 & 17.3 \\
Chemistry & 0 & - & 1 & 4.3 \\
Mathematics & 0 & - & 1 & 4.3 \\
Biology & 0 & - & 1 & 4.3 \\
Astronomy & 1 & 4.3 & 0 & 4.3 \\
Geology & 1 & 4.3 & & - \\
\hline
\end{tabular}

\section{Discussion}

The results of this study of social science and social scientist perceptions of gifted intelligence students and normal intelligence students are as follows. When looking at the personal characteristics of social scientists that direct their mental images, a social science researcher is viewed as a person who has multiple perspectives and strong communication skills. Accordingly, the verbal-linguistic mental area of social scientists is enhanced. The social scientist's research factor is higher for gifted intelligence participants than in normal intelligence participants. At the same time, the under-representation of digital and technological sources of research methodology suggests that there is a classical research technique in the minds of the participants overall. When the physical images of social scientist are examined, social scientists are imaged as being young, stylish, cheerful, not disabled and tall. This result does not overlap with the findings of other studies (Akcay, 2011; Buldu, 2006; Chambers, 1983; Flick, 1990; Fort and Varney, 1989), which reveal that scientists are thought of as old people. Moreover, participants in this study thought that social science studies were easier than natural sciences. Portrayal of social scientist without disability in both groups of participants is another significant finding. As for gender, it was found that the gender of the social scientist was significant and mostly perceived as male in both groups of participants, which has parallels with other studies (Demirbaş \& Coşkun, 2014; Fung, 2002; Gonsoulin, 2001; Kaya, Doğan, \& Öcal, 2008).

Overall participants understood the study area of social scientist as social life. In accordance with the nature of social science, this finding is important because social scientists are nested within society and culture and easy societal interaction. Yet, this finding does not overlap with findings from other studies (Finson et al., 1995; Kemaneci, 2012; Mead \& Metraux, 1957; Narayan et al., 2007), which suggest that the study area of the scientist is generally thought of as the laboratory. Another remarkable result is that normal intelligence participants imaged school or classroom as a social scientist's work place. Although this result draws attention to the educational side of social scientist's work, it also highlighted again that normal intelligence participants' source of social scientist is as a social science teacher.

When looking at participants' images of social scientists, it is usually one of happiness, even though social scientists do not dissociate from society and studies on the social life itself might be effective for this evaluation. This finding is consistent with results from recent studies (Akcay, 2011; Demirbaş \&Coşkun, 2014; Kemaneci, 2012; Öcal, 2007; Türkmen, 2008); however, it can also be interpreted as participants regarding science as an uplifting job, which leads to a cheerful image.

For participants, the object commonly used by the social scientist is human. In accordance with the nature of science, data are associated with human beings, which is both the reason for and actor who is doing science. Other studies (Schibeci, 2006; Sy-mington \& Spurling, 1990; Song \& Kim, 1999; Türkmen, 2008; Yontar-Toğrol, 2000) showed that human being is identified as the most common object of the scientist. Thus, there are clear parallels to the studies in which natural scientist are examined. Moreover, human being is the most commonly used object by scientists is a common image of natural and social sciences in the minds of almost all participants in this study. For gifted intelligence participants, the second most used object is the book, while the second most used object for normal intelligence participants is the class board. This study, then, has rediscovered that the source of social scientist perceptions of normal intelligence participants is a social science teacher.

When social scientist's activities and optimal discipline fields are symbolized, it can be said that both groups differ. While geography and archaeology were outstanding discipline fields according to gifted intelligent participants, social science teaching was optimal discipline field for normal participants. Arslan and Savaş (2017) suggests that participants who image archaeology have curiosity for revealing residuals of ancient civilizations and this curiosity can be effective for imaging archaeology. For geography, the reason for the selection was loving geography and wondering 
about nature. When questioned on this aspect, the result was like those from a previous study. In normal intelligence participants, the most important source of social science and social scientist perceptions is the social studies teacher.

Even though $86.9 \%$ of gifted intelligence participants were asked, none gave a name. For their favourite social scientist for normal intelligence participants the result was $78.2 \%$. The most repeated name among gifted intelligent participants was Ibn Sina. This situation shows that although gifted intelligence students can specifically understand social science, they do not recognize social scientists. The situation is similar for normal students. They confuse social sciences with natural sciences and give names of inventors and natural scientists, despite the questioning of social scientists. Accordingly, an inference can be made that both groups do not recognize social scientists sufficiently.

For $47.8 \%$ of gifted intelligence participants, the subject area of a social scientist is archaeological excavation. This is linked to the finding that archaeology is one of the most proper discipline fields for social scientists. And, for 26.08\% of normal intelligence participants, the most repeated subject area was 'world', so the whole world is a study area for social scientists.

While $87.4 \%$ of gifted intelligent participants can roughly distinguish social science from natural science, they have specifically imaged astronomy and geology as social sciences. Therefore, $87.4 \%$ of gifted intelligence participants can distinguish between social sciences and natural sciences and $65.2 \%$ of normal intelligence participants.

\section{Conclusion}

This qualitative study was conducted to compare the perceptions of students with gifted intelligence and students with those of normal intelligence about social science and social scientists. These groups were compared in terms of 11 criteria including mental image, physical image, gender, study area, happiness, object used, activity, optimal discipline field, favourite social scientist, research subject, relation between social science and natural science. According to the results, participants generally accepted the research interest of social scientist as a social life. A significant part of normal participants confused social science teacher with social scientist.

Perceptions of future social scientists are important for creating a correct mental image for social science and social scientists because it will affect the future attitudes and behaviours of participants and determine how social scientists are defined by other people. From this point of view, the perceptions accepted by people may be explanatory for their future attitudes and behaviours. Particularly by supporting the impression that female scientists are influential in the scientific world, students should be encouraged to develop a positive perception in this regard. The relevant units should be provided with comprehensive knowledge about social sciences. In this way, profound knowledge will be provided to students. At the same time, students' interests and curiosities should be taken into consideration in the design of the topics and activities, also strategies should be developed for students to move to areas of interest to social sciences and to increase their abilities. Likewise, representative studies for social scientist should be broadcasted in both media and printed press. Social science studies and social scientist biographies should be supported by video narration on the sites where educational contents are provided via the general internet network and students should be introduced to these channels. Similar studies should be conducted on different groups and according to results of them, correct and positive perceptions of students on social science and social scientists should be provided.

\section{References}

Akcay, B. (2011). Turkish elementary and secondary students' views about science and scientist. Asia-Pacific Forum on Science Learning and Teaching, 12(1), 1-11.

Arslan Ö., \& Savaş B. (2017). The secondary school 6th graders' perception of images of social scientists. ZfWT9(1), $177-189$

Babbie, E. R. (1990). Survey research methods. (2nd ed.). Belmont, CA: Wadsworth

Bristow, W. (2010). Stanford Encyclopedia of Philosophy. Retrieved from https://plato.stanford.edu/

Buldu, M. (2006). Young children's perceptions of scientists: A preliminary study. Educational Research, 48(1), 121-132. https://doi.org/10.1080/00131880500498602

Camc1-Erdoğan, S. (2013). Gifted and talented students' images of scientists. Turkish Journal of Giftedness and Education, 3(1), 13-37.

Chambers, D. W. (1983). Stereotypic images of the scientist: The draw a scientist test. Science Education, 67(2), 255-265. https://doi.org/10.1002/sce.3730670213 
Demirbaş, Ç. Ö., \& Coşkun M. (2014) Social scientist perception of undergraduate geography Students. Social and Behavioral Sciences, 120, 230-237. https://doi.org/10.1016/j.sbspro.2014.02.100

Esgin A., \&Arslan, F. (2011). Türkiye'de Sosyal Bilim Algısının Negatifliği ve Üniversitenin Misyonu Üzerine. Uluslararası Yüksekögretim Kongresi. 375-386.

Finson, K. D., \& Beaver, J. B. (1995). Development and field test of a checklist for the draw-a scientist test. School Science and Mathematics, 95(4), 195-205. https://doi.org/10.1111/j.1949-8594.1995.tb15762.x

Flick, L. (1990). Scientist in residence program improving children's image of science and scientists. School Science and Mathematics, 90(3), 204-214. https://doi.org/10.1111/j.1949-8594.1990.tb15536.x

Fort, D. C., \& Varney, H. L. (1989). How students see scientists: mostly male, mostly white, and mostly benevolent. Science and Children, 26(8), 8-13

Fung, Y. Y. (2002). A comparative study of primary and secondary school students' images of scientsts. Research in Science \& Technological Education, 20(2), 199-213. https://doi.org/10.1080/0263514022000030453

Gadamer, H. G. (1994). Truth in the human science. In Brice R. Wachterhauser (ed.), Hermeneutics and Truth. Northwestern University Press. Northwestern University Press.

Gonsoulin, W. B. (2001). How do middle school students depict science and scientist? (Un-published doctoral dissertation). Mississippi State University, Mississippi

Kara, B., \& Akarsu, B. (2013). Determining the attitudes towards and images of the scientists among middle school students. Journal of European Education, 3(1), 8-15

Kemaneci, G. (2012). Üstün yetenekli öğrencilerin bilim insanı hakkındaki imajlarının araştırllması (Unpublished Master Thesis). Gazi University, Ankara.

Köroğlu, C. Z. ve Köroğlu, M. A. (2016). About the development of science concept and current social sciences. PAU Journal Social Science, (25), 1-15

Mead, M., \& Metraux, R. (1957). Image of the scientist among high-school students. Science, 126(3270), 384-390. https://doi.org/10.1126/science.126.3270.384

Narayan, R., Park, S., \& Peker, D. (2007). Sculpted by culture: Students' embodied images of scientists. Proceedings of epiS-TEME, 3, 45-51.

Neuman, W. L. (2014). Toplumsal araştırma yöntemleri: nitel ve nicel yaklaşımlar. (S. Özge, Çev.). İstanbul: Yayın odasi.

Punch, K. F. (2014). Sosyal araştırmalara girişs: nitel ve nicel yaklaşımlar. (D. Bayrak, H. B. Arslan ve Z. Akyüz, Çev.). Ankara: Siyasal Kitabevi.

Song, J., \& Kim, K. (1999). How Korean students see scientists: The images of the scientist. International Journal of Science Education, 21(9), 957-977. https://doi.org/10.1080/095006999290255

Soysal, D. (2012). Gadamer'in doğalcılık eleştirisi. Tabula Rasa, 25(26), 58-569.

Turgut, H. (2008). Herkes için bilimsel okuryazarlık. Ankara Üniversitesi Eğitim Bilimleri Fakültesi Dergisi, 40(2), 233-256.

Yıldırım, A. ve Şimşek, H. (2005). Sosyal bilimlerde nitel araştırma yöntemleri. Ankara: Seçkin.

Yontar-Toğrol, A. (2000). Öğrencilerin bilim insanı ile ilgili imgeleri. Eğitim ve Bilim, 25(118), 49-57. 